\title{
FONEEM EESTI KEELES
}

\author{
P. ARISTE \\ filoloogiateaduste doktor
}

\begin{abstract}
Pärast J. V. Stalini töö „,Marksism ja keeleteaduse küsimused” ilmumist on nõukogude keeleteadus kiirete sammudega edasi astunud ning saanud maailma eesrindlikuks keeleteaduseks. On avaldatud pōhjalikke uurimusi keeleteaduse üldiste küsimuste kohta. On ilmunud ohtrasti töid eri keelte omapärast ja ajaloost. Marri araktšejevliku režiimi kehtimise ajal unarusse jäänud keele hääldusliku külje täpne uurimine on taas andnud tähtsaid teoseid, mida peab eriti alla kriipsutama, sest vene ja nõukogude keeleteadusel on foneetikateaduse arenemisel vanu kuulsusrikkaid traditsioone. Eriti pōhjalikult on viimasel ajal käsitletud seda foneetikaalast küsimust, mis on foneem. Foneemi olemuse kohta on olnud muide pikem diskussioon ühe asjaomase ajakirja veergudel ${ }^{1}$. Selle diskussiooni käigus on jôtud selgusele, mis on foneemi olemuseks ning ühtlasi ära năidatud, kuidas foneemi môistet on moonutanud ühelt poolt marristid ja teiselt poolt eriti lääne mitmesuguste keeleteaduse voolude esindajad, kōigepealt nn. fonoloogid. Diskussioonis on tõstetud ka see tōik esile, et eri keeltes on foneemid vägagi erinevad ja et iga keele foneemide süsteemi tuleb vaadelda vastava keele enese seisukohalt.

Eesti keel on õige keerulise foneetilise süsteemiga. See süsteem läheb üsna ilmsesti lahku nende keelte foneetilisest süsteemist, kust tavaliselt on toodud näidismaterjal, mida on kasutatud foneemi olemuse määratlemisel. Sellepärast tahetaksegi alljärgnevas lühidalt sellel peatuda, mis on eesti keeles foneem.
\end{abstract}

Enne kui asuda otse eesti keele foneemide vaatlusele, tuleb käsitleda seda, mida mõistetakse foneemina tänapäeva nõukogude keeleteaduses.

Tartu Olikooli omaaegne professor keeleteadlane J. Baudouin de Courtenay (oli Tartus 1883-1893) tōi foneemi mōiste esmakordselt esile. Foneem oli Baudouin de Courtenay esialgse arvamise järgi morfoloogiline. Tema eraldas nimelt füsioloogilistest häälikutest morfoloogilised, s. o. need häälikud, mis moodustavad sōnu. Seda Baudouin de Courtenay vaadet arendas edasi tema õpilane N. Kruševski. Kruševski võttiski tarvitusele sõna ,foneem". Ka tema vastandas kōne füsioloogilisele aspektile morfoloogilise aspekti. Tema arvates oli foneem foneetiliseks ühikuks, häälik aga kõnefüsioloogia ühikuks. Kruševski järgi võis foneemiks olla ka selliseid häälikute ühendeid, millest ta oletas, et need on jagamatud ning millel eri sugulaskeelis on erinevaid vasteid. Seega andis Kruševski foneemile etümoloogilise sisu ning eraldas ta täiesti häälikust. Nõnda pidas ta foneemiks slaavi häälikuteühendit $s$ t, sest sellele vastab mōnes teises

1 Известия Академни иаук СССР. Отделение литературы и языка XI, 1952; XII, 1953. 
slaavi keeles štš, või ühendit $m l^{\prime}$ vene sōnas земля, sest sellele vastab poola keeles palataliseeritud $m^{\prime}$ (zemia). Baudouin de Courtenay vôttis omaks Kruševski vaated ning püstitas nn. homogeenide teooria, s. o. teooria häälikuist või häälikute ühenditest, mis moodustavad homogeenseid morfeeme. Homogeenid jagas ta kahte tüüpi: divergentideks ja korrelatiivideks. Divergentideks nimetas ta sama hääliku teisendeid, mille on kutsunud esile kaasajal toimivad häälikuseadused. Korrelatiivideks nimetas ta aga antropofooniliselt, s. o. füsioloogiliselt erinevaid, kuid homogeenseid häälikuid, mille erinevusi pole võimalik seletada kaasaja tingimuste varal. Divergentide kohta soovitas Baudouin de Courtenay tarvitada oskussõna häälik ja korrelatiivide kohta oskussõna foneem. Ohtlasi andis Baudouin de Courtenay nüüd foneemi täpsema definitsiooni, mille järgi foneem on sõna teatud foneetilise osa üldistatud antropofooniliste omaduste summa, mis on jagamatu ühe keele korrelatiivsete seoste ning mitme keele korrespondentsete suhete kindlaksmääramisel. Teiste sōnadega: foneem on sõna foneetiliste osade võrdlemise vaatekohalt foneetiliselt jagamatu. Kõneldes foneemi ja hääliku suhteist osutas Baudouin de Courtenay, et foneem vōib vőrduda terviklikule häälikule, mittetäielikule häälikule (milleks ta pidas näiteks palataliseerimata ja palataliseeritud konsonante omavahel), terviklikule häälikule, millel on lisaks teise hääliku omadusi (näiteks $a-1$ eri häälikute naabruses), kahele või enamale häälikule (näit. ra ja oro vene sōnades вращать ја воротить, sest need sõnad kuuluvad etümoloogiliselt ühte ning neis esineb ra ja oro vaheldus). Seega ilmneb, et Baudouin de Courtenay pidas tollal foneemi kōigepealt ikkagi etümoloogilismorfoloogiliseks, mitte aga foneetiliseks ühikuks.

Tartus olles loobus Baudouin de Courtenay mõnel määral ülaltoodud foneemi möiste definitsioonist. Tollal arendas ta edasi divergentide mõistet, väites, et on olemas ühelt poolt tekkivat ja teiselt poolt elavat ehk nähtavat divergentsi. Tekkiv divergents kujuneb Baudouin de Courtenay arvates füsioloogiliste või antropofooniliste tegurite mõjul. Naabruse mōjul võib näiteks samal konsonandil olla küllaltki erinevaid divergente. Need divergendid pole omavahel etümoloogiliselt seotud. Edasi osutas Baudouin de Courtenay, kuidas elavad vöi nähtavad divergendid on kujunenud samuti füsioloogiliste tegurite mõjul, kuid seda üksnes ühe morfeeni piirides (nagu näiteks $t$ ja $d$ vene sônades $р о д=$ rot ja рода $=$ roda). Kōneleja teadvuses kuulduvat sama morfeem ikka ühesuguselt ning ta kavatsevat alati hääldada sama, kuid mōningad füsioloogilised tegurid ei laskvat seda toimuda.

Foneemi möistet arendas Baudouin de Courtenay üha edasi ning jõudis lōpuks tulemusele, et foneem on kõnehääliku psüühiline ekvivalent. Ta väitis, et foneemi tervikliku kujutlusega assotsieerub teatud summa üksikuid antropofoonilisi kujutlusi, mis on ühelt poolt artikulatsioonikujutlusi ja teiselt poolt akustilisi kujutlusi. Seega ei assotsieeru foneem Baudouin de Courtenay arvates mitte morfoloogilis-etümoloogiliste kujutlustega, nagu ta varemini oletas, vaid foneem assotsieerub akustilis-artikulatsiooniliste kujutlustega.

Hiljemini kaldus Baudouin de Courtenay foneemi määratluses üha enam psühholoogilisele positsioonile. Ta pidas nüüd foneemi psühhofoneetiliseks nähtuseks, kuigi ta ei loobunud lôplikult ka etümoloogilis-morfoloogilisest vaatekohast. Kaugemale Baudouin de Courtenay foneemi määratlemisel pole jöudnud ${ }^{2}$.

Baudouin de Courtenay ōpilane L. Stšerba on viinud foneemi küsimuse

2 Л. Р. 3 индер и М. И. М а тусев и ч, К исторни учения о фонеме. Нзвестия Академин наук СССР. Отделение литературы и языка, XII, 1953, Ik. 62-65. 
lahendamist suurel määral edasi. Stšerba on kōigepealt näidanud, miks akustilis-füsioloogiliselt omaduselt enam-vähem erinevad häälikud vōivad moodustada ühe foneetilise terviku ning miks võidakse eri keeltes samu häälikulisi erinevusi mitmel eri viisil ära kasutada. Stšerba vōttis foneemi määratlemisel aluseks tähenduskriteeriumi, mis siis võimaldaski tal jōuda öigetele tulemustele. Stšerba osutas, et ühtedel häälikutel on omadus tähendust eraldada, teistel seda aga ei ole. Esimesi nimetas ta foneemideks, teisi aga varjunditeks. Stšerba lähtus Baudouin de Courtenay divergentsiteooriast oma varjundite teooria loomisel. Ta osutas, et varjundid moodustavad siis ühe terviku - foneemi, kui kōneleja kujutluses nad ei esine iseseisvatena, kui nad kōneleja kujutluses ei eralda tähendusi. Et foneem on tähendusega otseselt seotud, sellele veendele jäi Stšerba edaspidigi oma mitmekülgsetes käsitlustes foneemi olemuse kohta. Ta näitas, et häälikuid ei kasutata keeles mitte lihtsate füüsikaliste või füsioloogiliste nähtustena, vaid keele elementidena, millel on tähendus. Stšerba järgi on seega foneemi omaduseks olla tähenduse potentsiaalseks kandjaks. Foneem on tema järgi köige lühem keeleelement, mida enam ei saa jagada. Kogu foneem on tähenduse väljendajaks, mitte tema mõni üksik osa. Stšerba on edasi osutanud, et pole absoluutselt kindlaid piire foneemi ja selle varjundite vahel, tuues näiteid selle kohta, kuidas varjund võib kujuneda iseseisvaks foneemiks ja vastupidi, kuidas foneem vōib muutuda varjundiks. Seega osutati, et foneem pole staatiline ühik, vaid et ta kujuneb asjaomase keele arenemise protsessis ${ }^{3}$.

Stšerba foneemiteooria on lōplikult viimistletud tema teoses «Фонетика французского языка» (1939). Siin on ta veelkordselt osutanud, et foneemi määrajaks on tähendus. Keele sihiks on olla suhtlemisvahendiks. Foneem on vähim suhtlemisvahendi osa, mis veel väljendab kindlat tähendust. Foneemi varjundite hulgas on asjaomases keeles üks varjund, mis mitmel eri pōhjusel on saanud tüüpiliseks. Seda tüüpilist varjundit peetaksegi foneemiks.

Stšerba foneemikäsitlus on saanud nõukoğude keeleteaduses üldise tunnustuse.

Stšerba foneemikäsitluse on võtnud üle ka fonoloogid N. Trubetzkoy ja R. Jakobson. Olles aga tugevasti F. de Saussure'i môju all on need keelemehed moonutanud Stšerba vaateid. Nende arvates on foneemi olemasolu peamiseks aluseks vastandlikkus, s. o. foneem saab olemas olla üksnes siis, kui talle leidub vastand, millega ta ei või segi minna. Alles vastandlikkus andvat vöimaluse tähendust eraldada.

Eesti keele foneemi küsimust on esmakordselt hakanud käsitlema selle artikli autor. Oma uurimuses „Hiiu murrete häälikud” (1939) on ta tahtnud osutada, mis on hilu murrakuis foneemiks ja mis foneemi varjundiks. Oma tolleaegseis käsitlustes on ta olnud üsna tugevasti fonoloogide vaadete mõju all. Foneemi olemasolu kindlaksmääramisel on „Hiiu murrete häälikuis" lähtutud kõigepealt just vastandlikkusest. Trubetzkoy foneemiteooriasse on siiski suhtutud kriitiliselt ning osutatud, et see ei ole kõigiti kehtiv eesti keele kohta, millel on keeruline kvantiteedisüsteem. Eesti keele foneemi olemasolu määratlemisel on lähtutud hääliku leksikaalsetest ning morfoloogilistest ülesannetest. On näidatud, „et mitte üksnes see ei ole tähtis foneemi määramisel, et foneemil oleks vastand, millega teda ei või vahetada või segi ajada, vaid ka hääldusharjumus, traditsioon on tähtis" 4. Samuti on tōstetud esile, et foneemi olemasolu määrab täpne aru-

3 L. Sćerba. Court exposé de la prononciation russe, Supplément du Maitre phonétique, nov-déc., Paris $1911 \mathrm{lk} .2$ jj-d; Л. Щ е р б a, Русскне гласные в качественном и колндественном отношенни, Петербург 1912, lk. 5 jj-d.

4 P. A riste, Hifu murrete häälikud, Tartu 1939, lk. 137. 
saamine ${ }^{5}$. „Hiiu murrete häälikuis" on toodud muıde esile ka see tõik, et eesti keeles vōivad foneemid olla kvalitatiivsed ja kvantitatiivsed.

Kui kirjutati „Hiiu murrete häälikuid”, ei tundnud autor Stšerba uuemaid töid foneemi kohta otseallikaist, vaid teadis neid üksnes tsiteeringute kaudu teiste autorite töödest. Seega polnud tollal veel vöimalik otseselt toetuda õigetele tulemustele, mis olid esile toodud Stšerba poolt.

Mis on siis eesti keeles foneemiks, kui vaadelda keelt marksistliku keeleteaduse seisukohalt?

Oma töös "Marksism ja keeleteaduse küsimused” on J. V. Stalin öelnud: „Häälikuline keel ehk sōnade keel oli alati inimühiskonna ainsaks keeleks, mis suudab olla inimeste suhtlemise täisväärtuslikuks vahendiks.... Häälikuline keel on inimkonna ajaloos üks neid jôude, mis aitasid inimestel eralduda loomariigist, ühineda ühiskondadeks, arendada oma mõtlemist, organiseerida ühiskondlikku tootmist, edukalt võidelda loodusjōududega ja jōuda selle progressini, mis meil on praegusel ajal" 6 . Häälikuline keel üldse on arenenud koos inimkonna arenemisega ja iga üksik keel on arenenud koos vastava kollektiiviga. Igas häälikulises keeles on kujunenud pikkade aegade jooksul oma foneemid, mille ülesandeks on pidada ühendust kōnelejate vahel, teenindada inimesi suhtlemisvahendina.

Mis tahes keeles ei tunnetata mitte. kõiki võimalikke füsioloogiliselt moodustatavaid häälikuid iseseisvateks kõnehäälikuteks, vaid üksnes neid, millel on kindel funktsioon. Pandagu selleks tähele eesti sõna kala, tala või $k u l u$, tulu. Neist sõnadest võib kõigepealt nentida, et $k$ ja $t$ eraldavad teineteisest tähendusi. Vastastikuses suhtlemises ei- või neid segi ajada, asendada, sest siis kannataks sellega öige arusaamine. Ka pole need häälikud jaotatavad vähemateks osadeks. Samuti eraldavad tähendusi $a$ ja $u$. Seega on $k$ ja $t$ vôi $a$ ja $u$ iseseisvad foneetilised ühikud, kva lit a $\mathrm{t} \mathrm{i} \mathrm{iv.}$ sed foneemid, mille varal toimub inimeste suhtlemine.

Eesti keeles hääldatakse sõnas toas kirjapilt o eri murretes õigegi erineva häälikuna. Murrete taust kajastub ulatuslikult rahvuskeeleski. Köigepealt võib esineda normaalne eesti $o$ : toàz. Teiseks võib olla $o$ ja $u$ vaheline hãälik $\dot{o}:$ tóáz. Edasi on võimalik selline $o$, mis on harilikust vaid veidi kõrgem, nimelt $\varrho$ : toàz. Need mainitud häälikud $o, \varrho$ ja $\delta$ koonduvad kōik üheks kvalitatiivseks foneemiks $o$, millel on oma kindel ühiskondlik funktsioon. Eesti keeles $o, O$ ja $o$ ei eralda omavahel mōisteid, nende asendumisel üksteisega sōna tähendus ei muutu. Eestlane tajub neid kōiki üheks. Seega on $o$ ja $\dot{\delta}$ üksnes foneemi $o$ varjundid. Samuti on $e$ või $e$ diftongides (éỏ 'eod', téàn 'tean') üksnes foneemi e varjundid. Foneemi $e$ teisendiks on ka louna-eesti murdeis esinev nn. taga- $e$ ehk $e$ tagavokaalseis sōnades: kęnęlẹs 'kōneleb', kalàlę 'kalale'. Eesvokaalseis sōnus vastab $e$-le harilik e: peześ 'peseb', ezàle 'isale'. Kōnesolevad häälikud $\varrho$ ja $e$ ei eralda tähendusi. Neid tajutakse sama foneemina, mis varieerub naabruses olevate vokaalide järgi. Naabruse järgi võib iga kvalitatiivne foneem varieeruda. Nōnda on $k$ sỗnades kala, kulu, kõla, kile, küla, käli jne. füsioloogiliselt igal juhul erinevalt moodustatud. Foneemina on olemas üksnes üks $k$, mis võib naabruse mõjul varieeruda.

Eesti keeles on foneemi olemuse küsimus keerulisem kui mõnes teises keeles keele omapärase kvantiteedisüsteemi tōttu. Eesti keeles on nimelt foneemideks ka häälikute välted. Sōnades koli, kooli (omastav) ja kooli

5 P. A r iste, Hiiu murrete häälikud, lk. 136.

- J, Sta $1 \mathrm{i} \mathrm{n}$, Marksism ja keeleteaduse küsimused, Tallinn 1952, Ik. 42. 
(osastav), s. o. koli, kōli ja kôli on olemas ainult üks vokaal o. Foneeme on aga esitatud juhtudel kolm, sest niihästi o kui ka $\bar{o}$ ja $\hat{o}$ eraldavad tähendusi. Kõik vokaali kolm väldet on seega ka kindlaks suhtlemisvahendiks kōnelejate vahel. Neid ei saa ühtlasi jagada vähemateks osadeks ning nende esinemine on üldine. Mida siin on öeldud $o$ kohta, see kehtib teistegi vokaalide suhtes. Samuti on eesti keeles foneemiks konsonantide välted. Sōnades lina, linna (omastav), linna (osastav), s. o. linà, lin̆nà, linnna on vaid üks $-n$ eri pikkustes. Jällegi on siin kolm foneemi, mis kõik on erinevate kommunikatiivsete ülesannetega. Eesti keeles esineb seega ka kvantitati ivseid foneeme.

Nagu kvalitatiivsetel foneemidel, nii on eesti keeles ka kvantitatiivsetel foneemidel varjundeid, mis ei ole iseseisvad. Nõnda on ülipikkadel foneemidel $\hat{a}, \hat{o}, \hat{e}$ jne. varjundiks natuke lühemad $\hat{a}, \hat{o}, \hat{e}$. Sõnades sâva, 'saada' ja sátta 'saata', lôga 'looga' (kaasaütlev sõnast lugu) ja lòkka 'looka' on eri pikkustega vokaalid, kuid käesoleval juhul erinev pikkus ei ole kommunikatiivsete ülesannetega. Lühikeste foneemide $a, e, i$ jne. teisenditeks on nende teises silbis esinevad poolpikad vasted $\dot{a}, \dot{e}, \hat{l}$ jne. Sõnades kalà 'kala', veDèl 'vedel', liGi 'ligi' on teise silbi vokaal esimese omast tunduvalt pikem korrektse hääldamise nõuete järgi. Esitatud sōnade tähendus ei muutu aga milgi viisil, kui hääldada poolpika vokaali asemele lühike: kala, vedel, ligi.

Helilisuse varieerumine ei anna eesti keeles erinevaid foneeme, nagu mōnes teises keeles. Eestlase kōrv tajub ikka üheks $s$-foneemiks selle kơik varjundid. Olgu hääldatud isà, izà või isegi $i z a \dot{a}$ 'isa' on eesti tavakeelega isikule sama, ehk küll füsioloogiliselt vōttes on tegu kolme erineva hääldamisvõimalusega. Samuti on eestlasele samaks foneemiks $b$ ja $B \sim p$, $d$ ja $D \sim t, g$ ja $a \sim k$, mis mõnes teises keeles võivad olla erinevaid foneeme. Uksnes sama foneemi varjunditeks on ka helilised ja helitud $m$ ja $m, n$ ja $N, l$ ja $L, r$ ja $R$ ning $v$ ja $v$. Olgu hääldatud kas mah̆l või mah́t 'mahl', lèhm või leh̀m 'lehm', kẹhr vōi kẹhr, 'kōhr', sellest ei olene eesti keeles sōna tähendus.

Eesti keeles on aga iseseisvateks foneemideks palataliseeritud konsonandid, sest nad on samasuguste iseseisvate kommunikatiivsete ülesannetega, nagu nende palataliseerimata vasted. Vōrreldagu selleks sōnu (seina) palk = palk ja (kuu)palk = palk, (lamba)tall =tal ja (hobuse) -

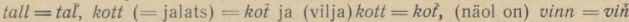
ja $(\mathrm{kaevu})$ vinn $=$ viñ jne.

Olalesitatu põhjal võib öelda, et eesti keeles on foneemide koosseis järgmine.

Foneemideks on kōik eesti keele vokaalid, $a, e, i, o, u, \bar{o}(=\ell), \ddot{a}, \ddot{o}$ ja $\ddot{u}$ kolmes vältes: $a, \bar{a}, \hat{a}, e, \bar{e}, \hat{e}, i, \hat{i}, \hat{i}, o, \bar{o}, \hat{o}$ jne.

Konsonantidest on foneemideks sulghäälikud $B, D, G$ (kirjas $b, d, g$ ) ja nende välted $\breve{p} p, \breve{t}, \breve{k}_{k}$ (kirjas $p, t, k$ ) ning $\dot{p} p, t t, \grave{k} k$ (kirjas $p p, t t, k k$ ): kaBì 'kabi', kap̆pi 'kapi', kappi 'kappi', kooà 'koda', kottà 'kota', kotta 'kotta'. Kombinatoorselt esinevad $k, p, t$ sõna alguses või helitute konsonantide järel (kašti 'kasti', kaśke 'kaske') on tegelikult $B, D, G$ varjun-

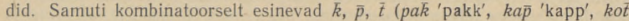
'kott'), $k, \dot{p}, \dot{t}$ (sàk 'saak', óp 'hoop', laut 'laut') ja kk, pp, tt (săkki 
'saak', óppi 'hoopi', lautta 'lauta') on $k k$, $\dot{p} p$, it varjundid. Teistest konsonantidest on foneemid $z, \breve{s} s, \dot{s} s$, mille varjunditel on samad suhted nagu sulghäälikute omadel. Et z, šs ja śs on omaette foneemid, osutavad sellised näited, nagu tazù 'tasu', tašsì 'käpa', tas̀su 'käppa'. Omaette foneemid on teistest konsonantidest $l$, $Y l$, ll (elà 'ela', ellà (omastav) 'hella', ella (osastav) 'hella'); $m$, mm, mm, (kamin 'kamin', kam̆min 'kammin', kammi (osastav) 'kammi'); n, n̆n, ǹn, (linà 'lina', lin̆nà (omastav) 'linna', linna (osastav) 'linna'); $r$, řr, irr, (nari 'nari', nar̆ri (omastav) 'narri', nairri (osastav) 'narri'); $h$, hh, hh (mehì 'mehi', tseh̆hì. 'tsehhis', tsehhi (sisseütlev) 'tsehhi'); v, ivv, (kavà 'kava', kaviva 'kavva') ja j (jací 'jagu'). Murdeti võib ka $h-1$ ja $v-1$ olla kolm vältusastet, nagu lōuna-eesti murdeis: kavà 'kava', kaข̆và (osastav) ja kavvva (sisseütlev).

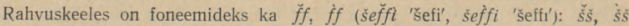
(tušši 'tuši', tuššsi 'tušši'). Kombinatoorselt esinevad f ja š (film 'film', $\dot{s} e \vec{f}$ 'šeff') on tegelikult vaid $\ddot{f f}-i$ ja $\breve{s} s-i$ teisendid. Lõpuks on rahvakeeles foneemiks ka ž (süžê 'süžee', želée 'želee'). Olalmainitud foneemidel vőib olla ka kvantitatiivseid kombinatoorseid teisendeid. Kuigi eesti ortograafia nōuete järgi kirjutatakse pikemaid konsonante kahekordselt, nagu pikki vokaalegi kirjutatakse kahe vokaalimärgiga, on tegu siiski vaid samade häälikute erinevate pikkusastetega. Eestlane tajub pikki häälikuid ikka üheks tervikuks, olgu nad öigekirjutuslikult kuidas tahes tähistatud. Muudelgi juhtudel ei tohi lasta ennast ei ortograafia ega foneetilise transkriptsiooni poolt eksiteele viia foneemide tōelise olemuse määratlemisel.

Eraldi tuleb veel peatuda $\eta-1$. Kombinatoorselt $g(=G)$ ja $k$ ees esinev $\eta$ on mōnel juhul tähendusegi eraldajaks. Seda osutavad sellised näited, nagu kò̀oi (sisseütlev) 'kongi' ja koǹci 'konngi', oijai 'hongi, suuri mände' ja oǹai 'ongi', kà̀oi (osastav) 'kangi' ja kaǹai 'kanngi' jne., kus ei ole võimalik $n$-i ja $n$-i ära vahetada, sest môlemal häälikul on mainitud juhtudel oma kommunikatiivne ülesanne, millest oleneb tähendus. Murretes esineb $\eta$ omaette foneemina veelgi ulatuslikumatel juhtudel,

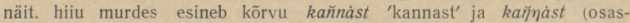
tav) 'kangast', vañnì 'vannid' ja vaĭmì 'vangid'.

Palataliseeritud konsonantidest on rahvuskeeles foneemid $\bar{D}$, it, $i t$ (loól 'lodi', loťti 'loti', lotti 'lotti'); í, šs, šs (każi 'kasi', kašsi (omastav) 'kassi', kašsi (osastav) 'kassi'); $l$, Ill, il (pali 'pali, kolmjalg', palli (omastav) 'palli', pailli (osastav) 'palli'); $\dot{n}, \quad \grave{n} n, \quad \dot{n} n$ (pani 'pıni', pañni (omastav) 'panni', paìni (osastav) 'panni'). Murretes esinevad ja kohati rahvuskeeleski on võimalikud ka $\dot{r}, \ddot{r}$, $\dot{r}$.

Tuleb kaaluda sedagi küsimust, kas eesti keeles pole foneemiks peale üksikhäälikute ja nende väldete ka diftongid. Nimelt on eesti keeles diftongidel kaks väldet. Kummalgi vältel on oma tähenduslik funktsioon, nōnda et kumbki välde on ühiskondliku suhtlemisvahendi môttes erinev. Diftongide väldete eri tähenduste tôttu on diftongid jagamatud. Sellega on eesti keele diftongidel olemas need omadused, mida eeldatakse foneemist. Pandagu selleks tähele selliseid sõnu, nagu laulu (omastav) $=$ laŭlu ja laulu (osastav) = laùlu, kaevu (omastav) = kaẽvù ja kaevu (sisse- 
ütlev) = kaèvu, seina (omastav $=$ seinà ja seina (osastav) $=$ seìna . Mitte ainult sama sōna diftongid oma väldetega pole iseseisvad foneemid, vaid ka eri tüvede diftongid oma väldetega, näit. lauda uks = laŭoá ja istus lauda $=$ laủba, tütarlaps Leida $=$ le lo $\dot{a}$ ja ei või leida $=$ leìna. Eesti keeles on siis vokaalfoneemide arv ōige suur, sest diftongid annavad omalt poolt juurde ohtrasti niihästi kvalitatiivseid kui ka kvantitatiivseid foneeme.

Eesti keeles pole mitte üksnes diftongid omaette foneemideks, vaid ka konsonantide ühendid. Samuti kui diftongid ei ole ainult vokaalide ühendid, vaid nad on üheks tervikuks liitunud foneetilised ühikud, nõnda on eesti keeles ka konsonantide ühendid tervikud, mis on jagamatud, mis on tervikuna tähenduse kandjaks ning ühiskondlikuks suhtlemisvahendiks. Pandagu selleks taas tähele selliseid sõnu, nagu kopsu (omastav) = kő̆sủ ja kopsu (osastav) = kopssu, marja (omastav) = mar̆jà ja marja (osastav) = marja, karjus on hoolas $=$ kar̆juz ja laps karjus $=$ karjuz, nalja (omastav) = naljà ja nalja (osastav) = nalja, kompsu (omastav) $=$ komp̆sì ja kompsu (osastav) $=$ komṕsu jne. Konsonantühenditega seoses tuleb mainida afrikaate, mis on samuti ilmekalt iseseisvad diftongid: metsa (omastav) = metsà ja metsa (sisseütlev) = metsa, matši (omastav) = matšs ja matši (osastav) $=$ matśsi.

Igale foneemile vastab harilikult oma kirjamärk, sest on vajalik, et ühiskondlik suhtlemisvahend oleks ka silmaga nähtav ning teiste foneemide tähististest kohe eraldatav. Eesti keele öigekirjutus on ses suhtes puudulik, et temas jääb terve rida foneeme märkimata, nagu toodud näidetest on selgunud. Kirjas ei osutata palataliseeritud foneeme ega $\eta$-i. Samuti on kirjas puudulikult tähistatud kvantitatiivsed foneemid.

Sama keele murretes võib olla erinevaid foneemide süsteeme. Mis ühes murdes on iseseisvaks foneemiks, ei tarvitse seda olla teistes murretes. Nōnda näiteks on eesti rahvuskeeles ja enamikus murretes $\ddot{o}$ ja $\tilde{o}(=\ell)$ omaette foneemid. Neid ei või segi ajada, sest neil on mõlemail kindel kommunikatiivne funktsioon. Hiidlastele ja enamikule saarlastele ei ole aga $\ddot{o}$ ja $\tilde{o}$ eri foneemideks. Hiidlastele pole samuti palataliseeritud ja palataliseerimata konsonandid omaette erinevaid foneeme. Eesti ühiskeeles ja murretes pole helilised $b, d, g$ ja $z$ foneemideks, kuid leivu ja lutsi murdes ning mônes Pihkva oblasti murrakus nad on siiski foneemid. Eesti rahvuskeele foneemide süsteem erineb üsna suuresti murrete omast. Rahvuskeeles on rahvusvaheliste ja vōōrsōnade kaudu keelde tulnud häälikud $(f, \breve{s}, \check{z}, t \check{s}, d \check{z})$ muutnud foneemide süsteemi.

Foneemist kõneldes tuleb veel peatuda foneemi varjunditel. Ulal on juba mainitud, et foneemi varjundid vōivad olla kombinatoorsed. Kombinatoorseid varjundeid on niihästi kvalitatiivsetel kui ka kvantitatiivsetel foneemidel. Kombinatoorsed varjundid on näit. $o, e$ ja $\ddot{o}$ diftongides (tóàz 'toas', téàn 'tean', pơàn 'pöan'); e lõuna-eesti murdeis (tulęt 'tuled'). Leenissulghäälikute $B, D, G$ ja $\mathrm{z}$ kombinatoorsed varjundid rahvuskeeles on $k, p, t$ ja $s$, heliliste $l, m, n, r$ ja $v$ kombinatoorsed varjundid on $L, M$, $N, R, V$ jne. Iseseisvaks foneemiks ei saa pidada ka w-häälikut, mis esineb näit. sōnades kă̋̈wà 'kaua', eŭwèz 'õues'. See häälik on tegelikult vaid foneemi $v$ kombinatoorseks varjundiks.

Foneemide varjundid vōivad olla ka maa-alalised. Sellised maa-alalised varjundid on näiteks $k, p, t$ kirde-eesti murdeis (kotà 'koda', tupà 'tuba', akà 'aga') B, D, G varjunditena. Maa-alalised varjundid on ka 
lõuna-eesti ja mõnede teistegi murrete $\dot{\delta}, \dot{e}, \delta$ rahvuskeele ja muude murrete $\hat{o}, \hat{e}, \hat{\delta}$ varjunditena.

Edasi vôivad foneemi varjundid olla isikupärased, individuaalsed. Foneemi $z$ individualse varjundina vōib isikuti kuulda $z$-d (izà 'isa')

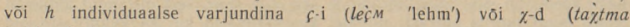
'tahtma') jne.

Igas keeles on kujunenud oma kindel foneemide süsteem. Keeles võib esineda ainult ajalooliselt kindlaks kujunenud foneeme. Foneemide esinemistingimused on samuti ajalooliselt kindlaks kujunenud. Keele fonoloogiline süsteem on üldiselt ôige püsiv. Eesti keeles elab tänini edasi selliseidki vanu fonoloogilisi traditsioone, mis on olnud ühised kõigile soomeugri keeltele, nagu see juht, et sõna alguses vōivad esineda üksnes fortissulghäälikud ja fortis-s. Eesti keele spetsiifika arenemise tulemusena on kujunenud aegade jooksul fonoloogiline süsteem, mis on omane üksnes sellele keelele. Eesti keele fonoloogilise süsteemi omapärast tuleb mainida järgmist.

Kōige omapärasemaks jooneks kogu eesti keele fonoloogilises süsteemis on keerulised kvantiteedisuhted ja astmevaheldus laadi- ja vältevaheldusena.

Eesti keeles on vokaalide esinemises õigegi erinevad võimalused sõna eri osades. Pearōhulises silbis vōivad esineda kõik vokaalfoneemid kolmes vältes. Samuti on diftongide arv selles asendis suur ning diftongidel on kaks väldet. Mujal sõna sees ei esine üldiselt $o, \tilde{o}, \ddot{a}, \vec{o}, \ddot{u}$ ja diftongide esinemine on üsna piiratud. Võib esineda üksnes $i$-lōpulisi diftonge, millel pealegi ei ole vältevaheldust. Kaugemal pearõhust ei esine harilikult pikki ega ülipikki vokaale, vaid esineb ainult lühikesi, või teises silbis ka poølpikki vokaale. Tüüpiline eesti keele fonoloogilisele süsteemile on just poolpika vokaali esinemine teises silbis, kui esimene silp pole ülipikk. Iseloomulik eesti keelele on veel vokaalide tugev nasaleerumine nasaalide mõjul.

Konsonantfoneemide suhtes iseloomustab eesti rahvuskeelt kōigepealt heliliste sulghäälikute $b, d, g$ ja helilise $z$ puudumine. Keele fonoloogilisele süsteemile pole omane konsonantide kuhjumine, vaid vokaalide ja konsonantide esinemine on enam-vähem tasakaalustatud. Eesti keeles ei või fortisklusiil ehk tugev sulghäälik ega $s$ esineda vokaalide vahel. Kui liitsõnas satub fortis vokaalide vahele, peab ta muutuma kas leeniseks või gemineeruma, sest vokaalidevahelises asendis tunneb eesti keel üksnes leeniseid (telźisäev, laŭlucōr, 'teisipäev, laulukoor'). Mõningais liitsōnades on eri tingimustel kujunenud geminatsioon (õunapuu hääldatakse eйnappu).

Keeles on kōik dünaamiline. Keele kui süsteemi eri osad ei muutu aga ühtlase kiirusega. Oldisest sõnavarast on püsivam sōnavara põhifond. Veelgi püsivam on keele grammatiline ehitus. Oige püsiv on ka hääldus, kuigi temas toimub pidevalt väikesi mutusi. Dünaamiline on keele fonoloogiline süsteemgi, mis vōib aegade jooksul muutuda. Varem pole olnud eesti keelele omased $\check{s}, \check{z}$ ja $f$. Ohiskeelele on aga need foneemid saanud omaseks. Praegusele eesti keelele ei ole võōras tarvitada konsonantühendit sõna alguses (praegu, trükkima, kliister), kuid keele ajalugu näitab, et varemini on konsonantühend sõna alguses olnud täiesti võimatu, nagu on olukord tänini mōnes murdes, kus öeldakse esitatud sõnade asemel ragu, rükkima, liister. Hiiu murre on läinud rahvuskeelest veelgi kaugemale, nōnda et selles murdes vōib sōna alguses esineda isegi kn-: knaakkas puu 'jändrik puu', knööp 'nööp'. 
Eesti rahvuskeelde on üsna hiljuti toodud konsonantühend $v d$, s. 0 . $v D$, mida keel pole varemini tundnud. Sellepärast hääldavad paljud keeletarvitajad seda uudset konsonantühendit valesti. Sõna tugevdada, vägevdada häăldatakse sageli tuceftava, väGeftada. See tōik osutab, et keele fonoloogiline süsteem on tugeva vastupanujổuga ega lase ennast kergesti muuta. Et eesti keele fonoloogiline süsteem ei tundnud $h$-d konsonandi järel, siis vōib kuulda, et sõnu sovhoos ja kolhoos hääldatakse mitut moodi olemasolevatele fonoloogilistele vôimalustele kohandades kas

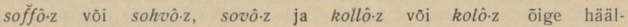
damise sovhó.z, kolhô.z asemel. Sõna arhiiv on isegi mōnede korrektset ühiskeelt kõnelevate isikute keeletarvituses ari.h. Eelnenud näidetest selgub, et $h$ ei ole veel kodunenud eesti keeles pearōhulise silbi algul sōna sees. See nähtus on vōrreldav $h$ kaoga sōna alguses, kus oma sõnadel on peãrōhk.

Eesti keele fonoloogilise süsteemi ōige järsuks muutumiseks oleks heliliste $b, d$ ja $g$ hääldamisele vōtmine rahvusvahelistes ja võōrsōnades, mida eri aegadel on soovitatud. Sellepärast polegi vastavad soovitused kõnelejate hulgas poolehoidu leidnud, vaid $b, d, g$ on jäänud üksnes foneemide $B, D, G$ individuaalseteks teisenditeks.

Interjektsioonid, onomatopoeetilised, vähemal määral ka deskriptiivsed, deminutiivsed, pejoratiivsed sōnad vōivad olla muust sõnavarast erineva fonoloogilise süsteemiga. Neis sõnades vōib esineda häälikuid, mis muus keele sônnavaras pole tavalised. Näiteks ei ole eesti keeles olemas imihäälikuid, kuid neid vōib siiski kuulda interjektsioonides. Lōuna-eesti murdeis esinevat kôrisulghäälikut ? vôib kuulda eitusinterjektsioonis a??. Isegi helilised sulghäälikud võivad interjektsioonides esile tulla.

Olaltoodud näited osutavad, et foneemi olemus on eri keeltes küllaltki erinev. Nõukogude Liidu rahvaste paljude keelte häälduse pōhjalik uurimine toob kaheldamatult esile veel teisigi foneemi olemasolu võimalusi, mida ei tunne eesti keel ega need keeled, mida seni on peamiselt vaadeldud foneemi mōistet käsitledes.

Tartu Riiklik Otikool

Saabus toimetusse 16. VI 1953.

\title{
ФОНЕМА В ЭСТОНСКОМ ЯЗЫКЕ
}

\author{
П. А. АРИСТЭ, \\ доктор филологических наук
}

Резюме

На страницах «Известий Академии наук СССР, Отделение литературы и языка» в 1952 году открылась дискуссия по вопросам фонологни. В ходе этой дискуссии был подвергнут серьезному обсуждению и вопрос о сущности фонемы.

Теория фонемы развивалась в русской лингвистической науке. Ее основоположником был И. А. Бодуэн де Куртенэ. Окончательное определение сущности фонемы дал советский языковед Л. В. Щерба. Л. В. Щерба показал, что сущность фонемы заключается в свойстве звука быть потенциальным носителем смысла, средством общения между людьми. Это определение сущности фонемы признано правильным современным со- 
ветским языкознанием. Фонема - кратчайший неделимый языковый элемент, от которого завнсит значение. Фонемы могут иметь оттенки. Нет абсолютных границ между оттенками и фонемами. Из оттенков могут образовываться самостоятельные фонемы, а самостоятельные фонемы, наоборот, могут превращаться в оттенки, так как фонема является исторической категорией, Фонема - совершенно конкретное звуковое представление, типовое представление, включающее всю совокупность оттенков.

В днскуссионных статьях «Известий» опнсываются фонематические системы разных языков, показывается зависимость сущности фонемы от общей системы данного языка. Приводится много правильных примеров относительно того, что именно является фонемой в отдельных языках. Приведенные примеры все жене показывают всесторонне, какие фонемы могут существовать вообще.

В данной статье описывается фонематическая система эстонского языка, произношение которого резко отличается от произношений в других языках.

Фонетическая система эстонского языка очень сложна. В ней коли. чество звуков играет особенно важную роль. Поэтому эстонский язык наряду с качественными фонемами имеет также и количественные фонемы. К качественным фонемам, напрнмер, относятся все гласные эстонского языка: $a, e, i, o, u, \tilde{o}, \ddot{a}, \ddot{o}, \ddot{u}$. Все гласные имеют трн степени долготы. От этих степеней долготы зависят лексические и морфологические значения слова, напрнмер: koli - дрянь (с кратким o), kooli - школы (с долгим o) и kooli - школу, в школу (со сверхдолгим o). Таким образом, все качественные гласные фонемы дают по три количественные гласные фонемы.

Качественными фонемами являются также все согласные эстонского национального языка $(k, p, t, m, n, s, \check{s}, \check{z}, l, r, f, v$, аффрикаты $t s, t \check{s})$. Фонемой нужно считать и звук $\eta$, который выступает только в связи с

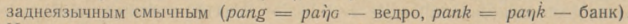
Имеются некоторые слова, где звуки $\eta$ и $n$ придают словам различное значенне, например, konngi $=k o \dot{n} \sigma i$ - даже лягушка и $k$ ong $i=k o \dot{q} i$ - в конуру. Все эстонские согласные также имеют степени долготы. Эти степени долготы согласных являются носителями смысла. Например, lina - лен (с кратким $n$ ), linna - (род.) го̀рода (с долгим $n$ ) и linna - в город (со сверхдолгим $n$ ).

Самостоятельными фонемами являются и палатализованные (смягченные) согласные $l^{\prime}, n^{\prime}, s^{\prime}, t^{\prime}$. Например, palk = palk - зарплата и palk $=$ pal'k - бревно.

Дифтонги эстонского языка нмеют две степени долготы: laulu = laŭlü - (род.) песни и laulu =laùla - песню, seina = seinả - (род.) стены и seina = seina - стену. Степень долготы имеют также сочетания согласных: marja = mar̆jà - (род.) ягоды и marja = marja - ягоду. Степени долтоты днфтонгов и сочетаний согласных являются носителями смысла. Они неделимы. Таким образом, нужно считать фонемами также дифтонги и сочетания согласных эстонского языка.

Звонкость согласных не дает в эстонском языке самостоятельных фонем. Звонкие и глухие звучания согласных являются лишь комбннаторными оттенками. Поэтому эстонец не различает $b, d, g$ от $p, t, k$ или же $s$ от $\boldsymbol{z}$.

Оттенки фонем эстонского литературного языка бывают комбннаторные, территориальные и индивидуальные. Имеются качественные и количественные оттенки. 
Фонетическая система эстонского литературного языка изменялась с течением времени. В литературный язык вошли фонемы $f, s, z z, t s ̌$, которые неизвестны большинству диалектов эстонского языка.

Как сам автор в своих прежних трудах, так и многие другие исследователи эстонского языка неправильно определяли сущность фонемы, и поэтому до настоящего времени не было правильного определения того, что именно является самостоятельной фонемой в эстонском литературном языке.

Тартуский государственный университет

Поступила в редакцню 16 VI 1953 